Article

\title{
Aqueous-phase Fischer-Tropsch synthesis catalyzed by cobalt nanoparticles
}

\author{
Hang Wang, Yuan Kou* \\ College of Chemistry and Chemical Engineering, Peking University, Beijing 100871, China
}

\section{A R T I C L E I N F O}

Received 21 January 2013

Accepted 2 August 2013

Published 20 October 2013

\section{Keywords:}

Aqueous-phase Fischer-Tropsch

synthesis

Cobalt nanoparticle

Boron contamination

In-situ infrared spectroscopy

\section{Article history:}

\begin{abstract}
A B S T R A C T
Converting syngas to hydrocarbons at much lower temperature with high efficiencies, namely aqueous-phase Fischer-Tropsch synthesis, has great potentials. In this article, we synthesized aqueous-stable cobalt nanoparticles for the reaction. The catalyst has an activity of $7.4 \times 10^{-7} \mathrm{~mol}_{\mathrm{co}}$ $\mathrm{g}_{\mathrm{co}^{-1}} \mathrm{~s}^{-1}$ and $\mathrm{C}_{5+}$ selectivity of $40 \%$, which is the best result in cobalt-catalyzed aqueous-phase Fischer-Tropsch synthesis. The catalyst is recyclable after reaction. We also characterized the catalyst by transmission electron microscopy, X-ray diffraction, and in-situ infrared observation to study the catalyst reconstruction process and boron contamination.
\end{abstract}

(C) 2013, Dalian Institute of Chemical Physics, Chinese Academy of Sciences. Published by Elsevier B.V. All rights reserved.

\section{Introduction}

The Fischer-Tropsch synthesis, a collection of chemical reactions which convert a mixture of carbon monoxide and hydrogen into liquid hydrocarbons, plays an important role in the indirect syngas liquefaction process and can convert coals, nature gas, biomass, and other energy sources into fuels and valuable chemicals [1-5]. In the past 80 years, supported and non-supported metal catalysts were studied extensively and found that some transition metals such as iron, cobalt, and ruthenium show good catalytic activity for Fischer-Tropsch synthesis [6-10]. Cobalt-based catalysts give the optimal choice for Fischer-Tropsch synthesis due to their good stability, high heavy hydrocarbon selectivity, and relatively low cost [8-10]. There are not only a number of industrialized examples on cobalt-based catalysts but also many laboratory researches on catalysts, supporters, reaction conditions, and other variables [10-12]. Noble metal promoters such as $\mathrm{Pt}, \mathrm{Ru}$, and $\mathrm{Pd}$ for Co-based catalysts are becoming attractive [13]. Moreover, people successfully adjusted the selectivity of reactions by optimizing the reactors and coupling multi-step reactions [14].

Because Fischer-Tropsch synthesis is highly exothermic, the reaction happening at relatively low temperatures would be more thermodynamically favorable, cleaner, and more environmental benign [15]. In our previous research, we achieved efficient aqueous-phase Fischer-Tropsch synthesis at a low temperature of $150{ }^{\circ} \mathrm{C}\left(200{ }^{\circ} \mathrm{C}\right.$ or above for traditional processes) by using $2.0 \mathrm{~nm}$ of $\mathrm{Ru}$ nanoparticles as catalyst, which was dispersed in water [16]. The catalyst showed a high stability in a flow system even after $240 \mathrm{~h}$ [17]. Quek et al. [18] later found that over $70 \%$ of oxygen-containing products could be obtained using surface-oxidized Ru nanoparticles. We also revealed that aqueous-phase Fischer-Tropsch synthesis was able to provide a platform for studying anionic additives as promoters [19]. All above examples exhibit significant advantages of aqueous-phase Fischer-Tropsch synthesis. Nevertheless, due to the high cost and scarce of $\mathrm{Ru}$, aqueous-phase Fischer-Tropsch synthesis using Fe- and Co-based catalysts is more

*Corresponding author. Tel: +86-10-62757792; Fax: +86-10-62751708; E-mail: yuankou@pku.edu.cn This work was supported by the National Basic Research Program of China (973 Program, 2013CB933100, 2013CB834603). 
practical. Although $\mathrm{FeC}_{x}$ as active species of $\mathrm{Fe}$ are too unstable in water to catalyze the synthesis, our group and Li's group. individually realized Fe nanoparticles catalyzed poly(ethylene glycol)-phase Fischer-Tropsch synthesis [20,21]. Co-based catalysts are more stable in water than Fe ones, which increases the possibility of successful Co-catalyzed aqueous-phase Fischer-Tropsch synthesis. There are only a handful of reports on Co-catalyzed liquid-phase Fischer-Tropsch synthesis so far. For examples, Silva et al. [22] achieved the catalytic activity of $1.9 \times 10^{-7}$ mol $_{\mathrm{CO}} \mathrm{g}_{\mathrm{Co}^{-1} \mathrm{~s}^{-1}}$ by dispersing Co-based catalyst in [Bmim] $\left[\mathrm{NTf}_{2}\right]$ at $210^{\circ} \mathrm{C}$. Our group achieved the catalytic activity of $6.1 \times 10^{-6}$ molco $_{\mathrm{gCo}^{-1}} \mathrm{~s}^{-1}$ by dispersing Co nanoparticles in squalane at $200{ }^{\circ} \mathrm{C}$ [23]. However, it is rare to report exclusively Co nanoparticles-catalyzed aqueous-phase Fischer-Tropsch synthesis with high activity.

In this work, aqueous-phase stable Co nanoparticles by using $\mathrm{LiBEt}_{3} \mathrm{H}$ as reducing agent were prepared and employed it in aqueous-phase Fischer-Tropsch synthesis at $150{ }^{\circ} \mathrm{C}$. The Co nanoparticles prepared by other reducing agents just showed poor catalytic activity. We also compared the properties of various catalysts, especially for the catalysts reduced by LiBEt$_{3} \mathrm{H}$ and $\mathrm{NaBH}_{4}$.

\section{Experimental}

\subsection{Catalyst preparation}

For the preparation of Co nanoparticles reduced by $\mathrm{LiBEt}_{3} \mathrm{H}$, $30 \mathrm{~mL}$ THF dissolved $0.26 \mathrm{~g} \mathrm{CoCl}_{2}$ and $0.50 \mathrm{~g} \mathrm{SB3-12}$ (n-dodecyl- $N, N$-dimethyl-3-ammonio-1-propanesulfonate, as a protective agent), then $5 \mathrm{~mL} \mathrm{LiBEt}_{3} \mathrm{H}$ in THF solution $(1 \mathrm{~mol} / \mathrm{L})$ was slowly injected by syringe with well stirring. The mixed solution quickly turned to black from blue, which indicated the reduction of cobalt. The reaction was quenched by $10 \mathrm{~mL}$ of ethanol after $10 \mathrm{~min}$, followed by separation of nanoparticles with a permanent magnet. After washing twice with ethanol and then twice with water, nanoparticles were dispersed in water, which contained $2.20 \mathrm{~g}$ of PVP (polyvinylpyrrolidone, as nanoparticle aqueous phase protective agent) and then was ready for using. It was referenced as $\mathrm{Co}-\mathrm{LiBEt}_{3} \mathrm{H}$.

For the preparation of Co nanoparticles reduced by $\mathrm{NaBH}_{4}$, $30 \mathrm{~mL}$ water dissolved $0.50 \mathrm{~g} \mathrm{Co}(\mathrm{OAc})_{2} \cdot 4 \mathrm{H}_{2} \mathrm{O}$ and $2.20 \mathrm{~g}$ PVP, then $0.40 \mathrm{~g}$ of $\mathrm{NaBH}_{4}$ was added with well stirring. The mixed solution quickly turned to black from red, which indicated the reduction of cobalt. The nanoparticles were separated by a permanent magnet. After washing twice with water, nanoparticles were dispersed in water, which contained $2.20 \mathrm{~g}$ of PVP and then was ready for use. It was referenced as $\mathrm{Co}-\mathrm{NaBH}_{4}$.

The preparation of Co nanoparticles by thermal reduction with $\mathrm{N}_{2} \mathrm{H}_{4}, \operatorname{LiAl}(\mathrm{O}-t \mathrm{Bu})_{3} \mathrm{H}, \mathrm{KH}$ or ethylene glycol and thermal decomposition of $\mathrm{Co}_{2}(\mathrm{CO})_{8}$ are followed in literatures [24-27].

All above synthetic processes were operated under the protection of $\mathrm{N}_{2}$.

\subsection{Characterization of catalysts}

Transmission electron microscopy (TEM) of nanoparticles was performed using a Tecnai F-30 electron microscope with working voltage of $300 \mathrm{kV}$. To prepare the testing sample, nanoparticles were first diluted in deionized water under the ultrasonication for $5 \mathrm{~min}$, and then a drop of solution was placed on an ultrathin carbon film coated copper grid. The statistical quantity of particle size distribution of each sample was over 200 particles.

X-ray powder diffraction (XRD) measurements were performed using a Rigaku D/MAX-2400 X-ray diffractometer with $\mathrm{Cu}$ anode, $K_{\alpha}$ radiation $(\lambda=0.154 \mathrm{~nm})$, voltage of $30 \mathrm{kV}$, current of $100 \mathrm{~mA}, 2 \theta$ scan range of $30^{\circ}-70^{\circ}$, scan rate of $2^{\circ} / \mathrm{min}$, and step size of $0.02^{\circ}$. Before processing to test, nanoparticles were separated by magnets, washed with water twice, and then dried under vacuum.

The amounts of Co and B in samples were determined by inductively coupled plasma atomic emission spectrometry (ICP, Perkin Elmer Optima 2000 DV). The samples were dissolved in $\mathrm{HNO}_{3}$ and $\mathrm{HCl}$.

The Fourier-transformed infrared spectroscopy (FTIR) of CO absorption of catalysts was performed at $150{ }^{\circ} \mathrm{C}$ and $3 \mathrm{MPa}$. The spectra were collected by a Bruker TENSOR 27 infrared spectrometer with resolution of $2 \mathrm{~cm}^{-1}$ and acquisition times of 64.

\subsection{Evaluation of catalysts}

The performance of Co nanoparticles for Fischer-Tropsch synthesis was examined in a closed stirred reactor. Co nanoparticles was dispersed in $40 \mathrm{~mL}$ of water and then transferred into the stainless steel reactor. After purging the reactor by $\mathrm{N}_{2}$ three times, 3.0 MPa of syngas ( $\left.\mathrm{CO}: \mathrm{H}_{2}: \mathrm{Ar}=32: 64: 4\right)$ was refilled. Fischer-Tropsch synthesis performance was measured at designated temperatures under stirring (800 r/min) until the total pressure decreased to $2.0-2.5 \mathrm{MPa}$ (corresponding to a CO conversion of about 20\%-30\%). Except for the cases of very slow reaction rates, the reaction time required was in the range of $24-48 \mathrm{~h}$.

As the reaction temperature returned to normal, the reactor was connected to a gas chromatograph (GC) to analyzed gas products. Then to the reactor $20.0 \mathrm{mg}$ of decalin as internal standard and $10 \mathrm{~mL}$ of cyclohexane as extraction agent were injected. After stirring at $150{ }^{\circ} \mathrm{C}$ for $2 \mathrm{~h}$, the reactor was cooled to room temperature and the cyclohexane layer was analyzed by GC to determine the liquid products.

In the recycle experiments, the Co nanoparticles were separated by magnet and then washed with deionized water twice before dispersed in the water containing $2.20 \mathrm{~g}$ of PVP and transferred to the stainless steel reactor for next round of reaction. The entire process was under the protection of nitrogen.

\section{Results and discussion}

\subsection{Particle size distributions of Co nanoparticles}

The TEM results of various Co catalysts are shown in Figs. 1-3. In Fig. 1 the TEM images and size distribution of Co-LiBEt ${ }_{3} \mathrm{H}$ catalyst before and after use for Fischer-Tropsch 

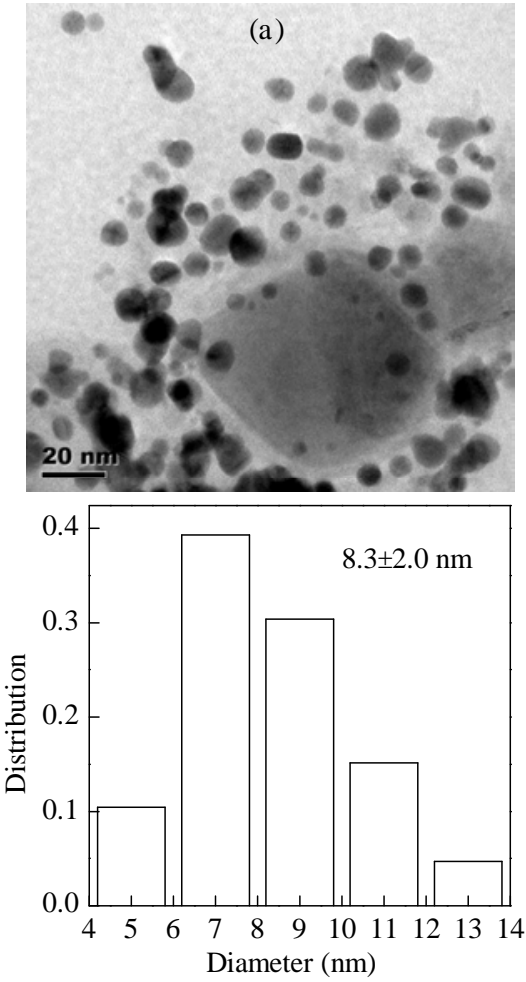
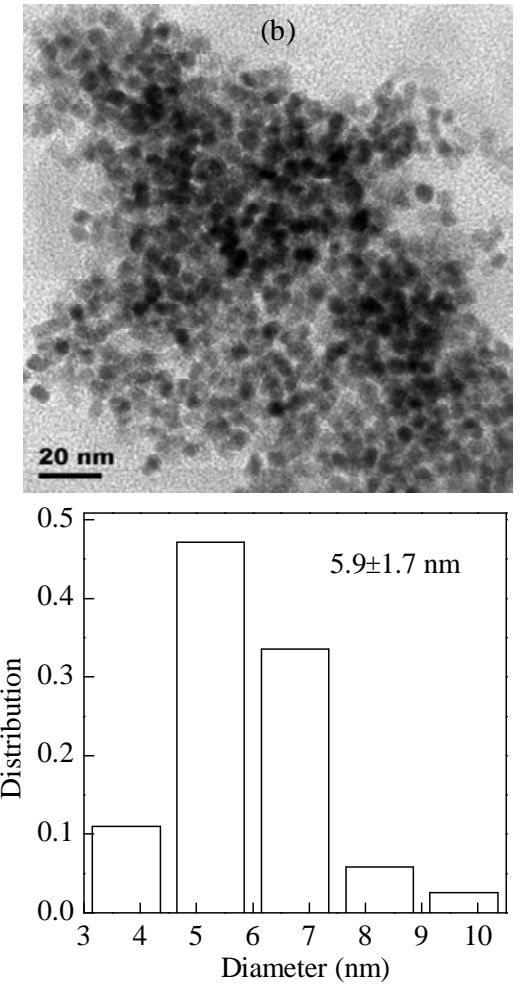
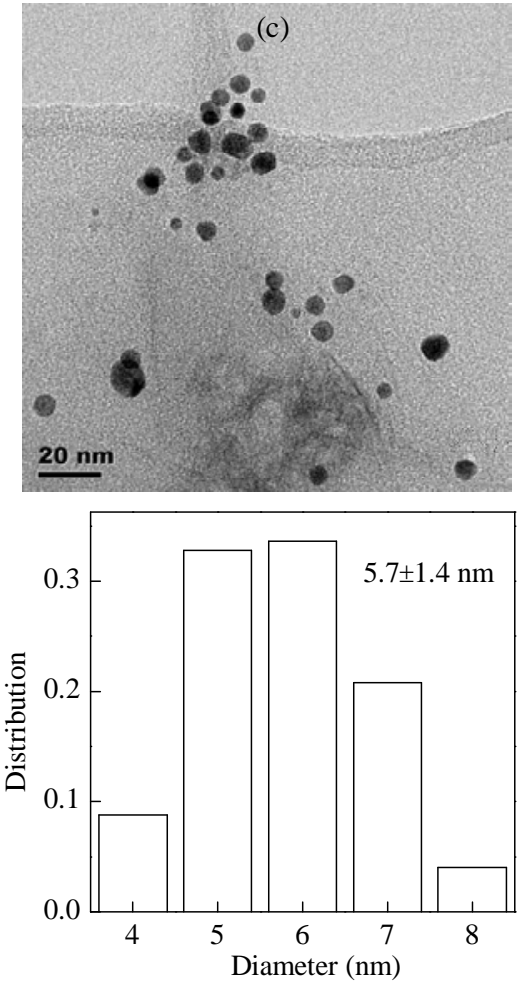

Fig. 1. TEM images and size distribution for Co-LiBEt $3 \mathrm{H}$ nanoparticles. (a) Before reaction; (b) After 1st reaction; (c) After 2nd reaction.

synthesis are shown. It's found that the average particle size of as-prepared Co nanoparticles before reaction is $8.3 \mathrm{~nm}$ (see Fig. 1(a)). After 1st reaction, there are a certain physical aggregations due to the wrap of products. The average particle size is $5.9 \mathrm{~nm}$, which means a reconstruction of nanoparticles under the reaction condition. But the average particle size of nanoparticles almost remains unchanged after repeated reactions. The average particle size is $5.7 \mathrm{~nm}$ after $2 \mathrm{nd}$ recycle reaction, which exhibited a good stability of Co nanoparticles.

As for $\mathrm{Co}-\mathrm{NaBH}_{4}$ nanoparticles, shown in Fig. 2, there is a significant change before and after reaction. The average particle size is $14 \mathrm{~nm}$ with a broad distribution before reactions (Fig. 2(a)), which changes to only be $3.1 \mathrm{~nm}$ after reactions (Fig. 2(b)). In addition, $\mathrm{Co}-\mathrm{NaBH}_{4}$ nanoparticles lose their magnetism after reaction so that they fail to be recycled by magnets.

The TEM images of Co nanoparticles reduced by $\mathrm{N}_{2} \mathrm{H}_{4}$, $\mathrm{LiAl}(\mathrm{O}-\mathrm{BBu})_{3} \mathrm{H}$, and $\mathrm{KH}$ are shown in Fig. 3. Because reduced nanoparticles seriously aggregate to too large pellet structure to be dispersed well, a flocculent form exists after preparation so that it is unsuitable to serve as catalysts for Fischer-Tropsch synthesis. As for the Co catalysts prepared by thermal reduction of ethylene glycol or thermal decomposition of $\mathrm{Co}_{2}(\mathrm{CO})_{8}$ (Fig. 4), overlarge particle sizes, 340 and $31 \mathrm{~nm}$, respectively, are obtained due to the employment of the low-protective stabilizer (SB3-12) and high synthesis temperature, which are not suitable for Fischer-Tropsch synthesis.

\subsection{Catalytic performance of catalysts for Fischer-Tropsch synthesis}

The catalytic performance of various Co nanoparticle catalysts for Fischer-Tropsch synthesis is listed in Table 1. Co-LiBEt ${ }_{3} \mathrm{H}$ shows a high catalytic activity, i.e. at $130{ }^{\circ} \mathrm{C}$ the activity is significant; at $150{ }^{\circ} \mathrm{C}$ the activity is $7.4 \times 10^{-7}$ molco $\mathrm{g}_{\mathrm{Co}}{ }^{-1} \mathrm{~s}^{-1}$, which is similar to the activity of $\mathrm{Co} / \mathrm{Al}_{2} \mathrm{O}_{3}$ at $190{ }^{\circ} \mathrm{C}$
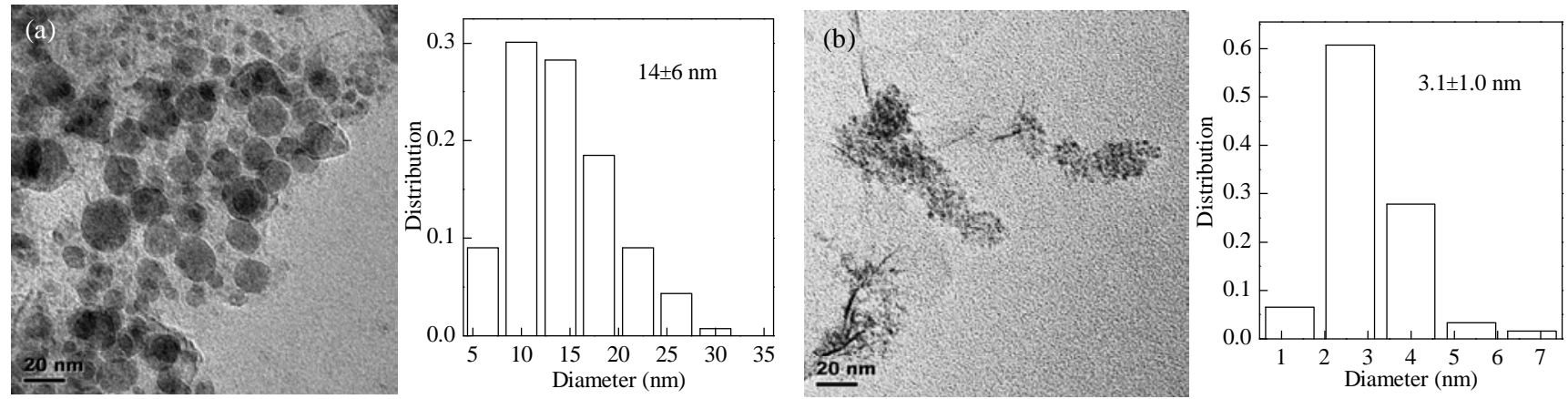

Fig. 2. TEM images and size distribution for $\mathrm{Co}-\mathrm{NaBH}_{4}$ nanoparticles. (a) Before reaction; (b) After reaction. 

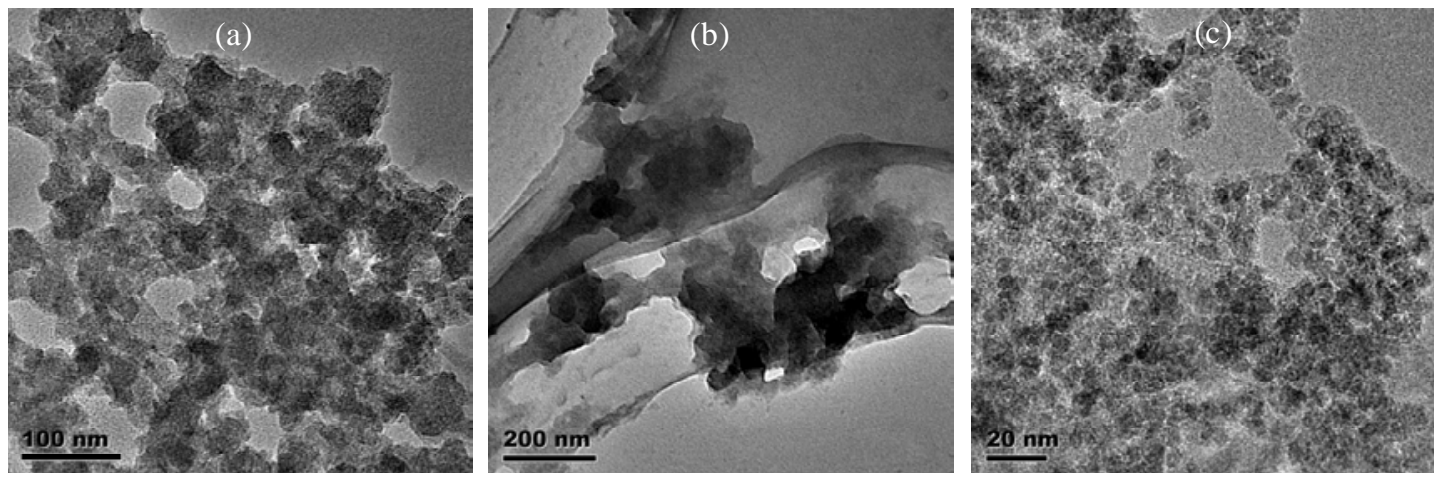

Fig. 3. TEM images of Co nanoparticles reduced by $\mathrm{N}_{2} \mathrm{H}_{4}(\mathrm{a})$, $\mathrm{LiAl}(\mathrm{O}-\mathrm{tBu})_{3} \mathrm{H}(\mathrm{b})$, and $\mathrm{KH}(\mathrm{c})$.
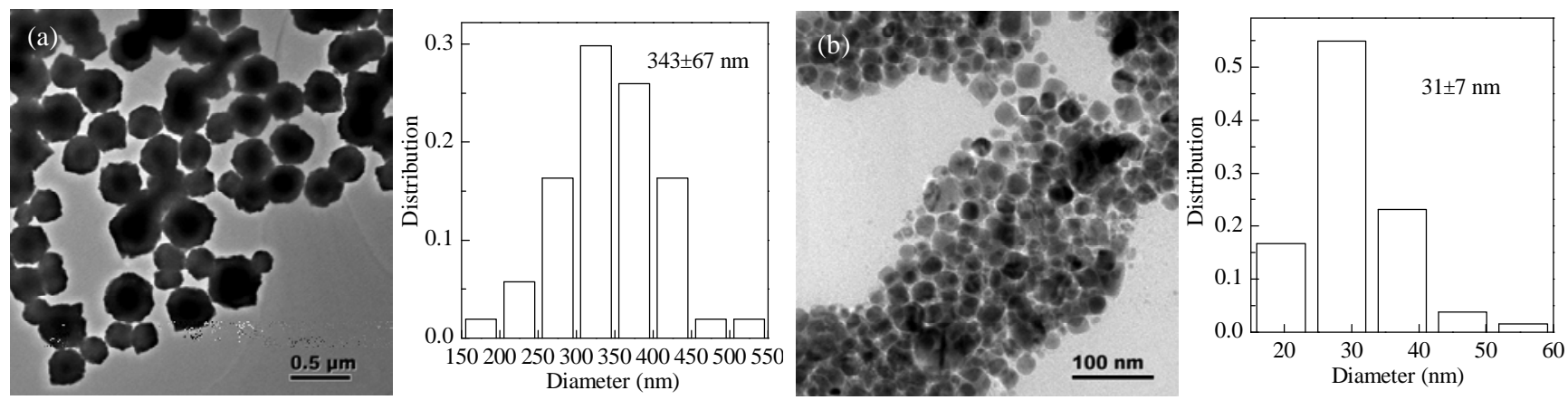

Fig. 4. TEM images and size distribution of Co nanoparticles prepared by thermal reduction of ethylene glycol (a) and thermal decomposition of $\mathrm{Co}_{2}(\mathrm{CO})_{8}(\mathrm{~b})$.

reported by Bechara et al. [28]; the activity increases to $1.3 \times$

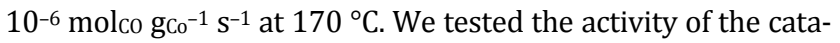
lyst at $150{ }^{\circ} \mathrm{C}$ under the five times recycles (entries $4-8$ ). The

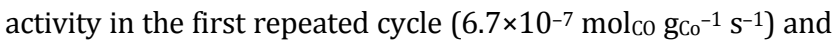
second repeated cycle $\left(5.9 \times 10^{-7}\right.$ molco $\left._{\mathrm{g}_{0}}{ }^{-1} \mathrm{~s}^{-1}\right)$ decreases slightly, while keeps stable in the following recycles. The recy-

Table 1

Catalytic performance of various Co nanoparticle catalysts.

\begin{tabular}{|c|c|c|c|}
\hline Entry & Catalyst & $\begin{array}{c}\text { Temperature } \\
\left({ }^{\circ} \mathrm{C}\right)\end{array}$ & $\begin{array}{c}\text { Activitya } \\
\left(10^{-7} \text { mol }_{\operatorname{cog}} \mathrm{g}_{\left.\mathrm{Co}^{-1} \mathrm{~s}^{-1}\right)}\right.\end{array}$ \\
\hline 1 & Co-LiBEt ${ }_{3} \mathrm{H}$ & 130 & 2.8 \\
\hline 2 & Co-LiBEt ${ }_{3} \mathrm{H}$ & 150 & 7.4 \\
\hline 3 & Co-LiBEt ${ }_{3} \mathrm{H}$ & 170 & 13 \\
\hline 4 & $\mathrm{Co}_{-\mathrm{LiBEt}_{3} \mathrm{H}}$ & $150^{\mathrm{b}}$ & 6.7 \\
\hline 5 & $\mathrm{Co}_{-\mathrm{LiBEt}_{3} \mathrm{H}}$ & $150^{\mathrm{c}}$ & 5.9 \\
\hline 6 & Co-LiBEt ${ }_{3} \mathrm{H}$ & $150^{\mathrm{d}}$ & 5.4 \\
\hline 7 & Co-LiBEt ${ }_{3} \mathrm{H}$ & $150^{\mathrm{e}}$ & 5.6 \\
\hline 8 & $\mathrm{Co}_{-\mathrm{LiBEt}_{3} \mathrm{H}}$ & $150^{\mathrm{f}}$ & 5.2 \\
\hline 9 & Co-NaBH ${ }_{4}$ & 130 & 1.2 \\
\hline 10 & $\mathrm{Co}-\mathrm{NaBH}_{4}$ & 150 & 3.3 \\
\hline 11 & Co-NaBH 4 & 170 & 4.7 \\
\hline 12 & $\mathrm{Co}-\mathrm{NaBH}_{4}$ & $150^{\mathrm{b}}$ & $\sim 0$ \\
\hline 13 & Co- $\mathrm{N}_{2} \mathrm{H}_{4}$ & 150 & 0.5 \\
\hline 14 & Co- $\operatorname{LiAl}(\mathrm{O}-t \mathrm{Bu})_{3} \mathrm{H}$ & 150 & 0 \\
\hline 15 & Co-KH & 150 & 0 \\
\hline 16 & Co-EG & 150 & 0 \\
\hline 17 & $\mathrm{Co}_{-} \mathrm{Co}_{2}(\mathrm{CO})_{8}$ & 150 & 0 \\
\hline 18 & blank & 150 & 0 \\
\hline
\end{tabular}

a Calculated based on $\mathrm{CO}$ conversion and steam transferred $\mathrm{CO}_{2}$ was removed. ${ }^{b} 1$ st recycle. ${ }^{c} 2$ nd recycle. ${ }^{d} 3$ rd recycle. e 4 th recycle. ${ }^{\text {f }} 5$ th recycle.

Reaction conditions: $150{ }^{\circ} \mathrm{C}, \mathrm{CO}: \mathrm{H}_{2}: \mathrm{Ar}=32: 64: 4$ (initial pressure 3.0 $\mathrm{MPa})$. cle experiments show the good long-time activity of Co- $\mathrm{LiBEt}_{3} \mathrm{H}$, also indicate that $5.9 \mathrm{~nm}$ of Co nanoparticles is stable after reconstruction from $8.3 \mathrm{~nm}$ of particles so that the catalytic activity can be remained.

As for $\mathrm{Co}-\mathrm{NaBH}_{4}$, its catalytic activity is lower than that of Co-LiBEt $3 \mathrm{H}$ at $130-170{ }^{\circ} \mathrm{C}$. If plotting the logarithm of the activity of catalysts and $1 / T$, shown in Fig. 5 , we can see that the

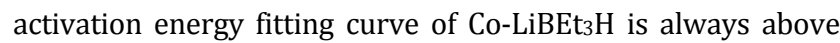
the curve of $\mathrm{Co}-\mathrm{NaBH}_{4}$ and the former is relatively largely affected by temperature with activation energy of $57 \mathrm{~kJ} / \mathrm{mol}$, while the latter has activation energy of $45 \mathrm{~kJ} / \mathrm{mol}$. In addition, Co- $\mathrm{NaBH}_{4}$ loses its activity after one time of reaction at $150{ }^{\circ} \mathrm{C}$ (Table1, entry 12), which means that the activity of 3.1 nm-particles decreases after reconstructed from initial parti-

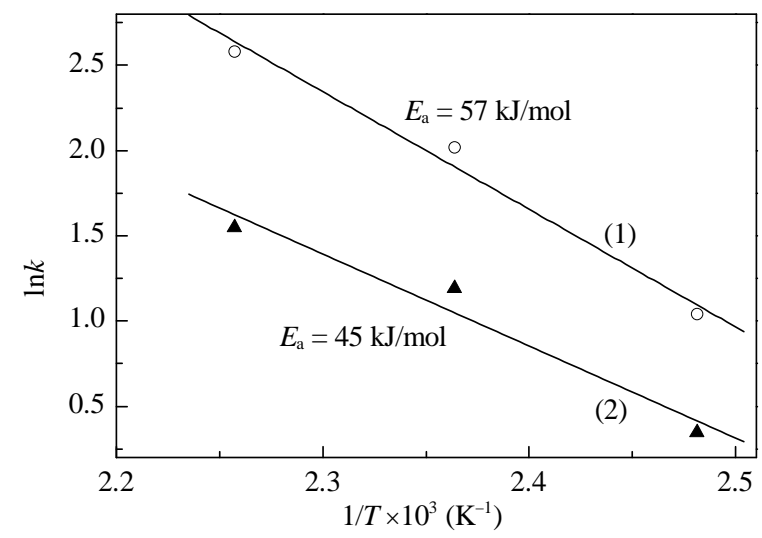

Fig. 5. Activation energy fitting curves of $\mathrm{Co}_{-\mathrm{LiBEt}_{3} \mathrm{H}}$ (1) and $\mathrm{Co}-\mathrm{NaBH}_{4}$ (2) catalysts. 
Table 2

Product selectivities of Co-LiBEt 3 H and Co- $\mathrm{NaBH}_{4}$ catalysts.

\begin{tabular}{|c|c|c|c|c|c|c|}
\hline \multirow{2}{*}{ Entry } & \multirow{2}{*}{ Catalyst } & \multirow{2}{*}{$\begin{array}{c}\text { Temperature } \\
\left({ }^{\circ} \mathrm{C}\right) \\
\end{array}$} & \multicolumn{4}{|c|}{ Selectivity (wt $\%$ ) } \\
\hline & & & $\mathrm{CH}_{4}$ & $\mathrm{CO}_{2}$ & $\mathrm{C}_{2-4}$ & $\mathrm{C}_{5+}$ \\
\hline 1 & $\mathrm{Co}_{-\mathrm{LiBEt}_{3} \mathrm{H}}$ & 150 & 26 & 9 & 26 & 39 \\
\hline 2 & $\mathrm{Co}_{-\mathrm{LiBEt}_{3} \mathrm{H}}$ & 170 & 29 & 8 & 28 & 35 \\
\hline 3 & $\mathrm{Co}-\mathrm{NaBH}_{4}$ & 150 & 33 & 5 & 41 & 21 \\
\hline 4 & $\mathrm{Co}-\mathrm{NaBH}_{4}$ & 170 & 40 & 7 & 36 & 17 \\
\hline 5 & Co- $\mathrm{NaBH}_{4}$ & $150^{\mathrm{a}}$ & 56 & 3 & 35 & 6 \\
\hline
\end{tabular}

a Using methanization condition of $\mathrm{CO}: \mathrm{H}_{2}=1: 10$.

cles. The activities of Co nanoparticles reduced by other methods are not observed in Fischer-Tropsch synthesis (Table 1, entries 13-17).

The selectivity of $\mathrm{Co}-\mathrm{LiBEt}_{3} \mathrm{H}$ and $\mathrm{Co}-\mathrm{NaBH}_{4}$ are shown in Table 2 and Fig. 6 . At $150{ }^{\circ} \mathrm{C}$, the products from Co- $\mathrm{LiBEt}_{3} \mathrm{H}-$ catalyzed Fischer-Tropsch synthesis contain $26 \%$ of methane, $26 \%$ of $\mathrm{C}_{2-4}$, and nearly $40 \%$ of $\mathrm{C}_{5+}$ products; at $170{ }^{\circ} \mathrm{C}$, the amount of methane increases and $\mathrm{C}_{5+}$ products decrease. As shown in Fig. 6(a), a half amount of $\mathrm{C}_{2+}$ products is olefin $(43 \%$ of $\mathrm{C}_{2-4}, 37 \%$ of $\mathrm{C}_{5-12}, 37 \%$ of $\mathrm{C}_{13+}$ ), which is the typical result of reactions happening at low temperature. At $150{ }^{\circ} \mathrm{C}$, the products over $\mathrm{Co}-\mathrm{NaBH}_{4}$ contain $33 \%$ of methane, over $40 \%$ of $\mathrm{C}_{2-4}$ and only $20 \%$ of $\mathrm{C}_{5+}$ products, and the distribution of olefin is similar to that of $\mathrm{Co}_{-} \mathrm{LiBEt}_{3} \mathrm{H}$; at $170{ }^{\circ} \mathrm{C}$, the amount of $\mathrm{C}_{5+}$ products further decreases. If the mixed gas of $\mathrm{CO}: \mathrm{H}_{2}=1: 10$ is employed, the amount of methane will be $56 \%$ with only $6 \%$ of $\mathrm{C}_{5+}$ products at $150{ }^{\circ} \mathrm{C}$. This shows that chain growth of Co-LiBEt ${ }_{3} \mathrm{H}$ is much better than that of $\mathrm{Co}-\mathrm{NaBH}_{4}$. In Fig. 6(b), the products of the two catalysts match Schulz-Flory distribution, and the former chain growth factor of Co-LiBEt $3 \mathrm{H}(0.70)$ is higher than $\mathrm{Co}-\mathrm{NaBH}_{4}$ (0.62).

The results above demonstrate that the catalytic activity, recycling ability and heavy hydrocarbon selectivity of Co-LiBEt 3 H catalyst are higher than those of $\mathrm{Co}-\mathrm{NaBH}_{4}$ catalyst. One possible reason is the difference of particle sizes of the two catalysts. Bezemer et al. [29] employed carbon fiber-supported Co catalysts in Fischer-Tropsch synthesis and found that particle size of Co catalysts should be about $6 \mathrm{~nm}$ in order to achieve the best activity, and the activity decreased observably if particle size is lower than $6 \mathrm{~nm}$, which decreases the trend of desorption of $\mathrm{CO}$ from the surface of $\mathrm{Co}$ as well as the formation of $\mathrm{B}_{5} \mathrm{CO}$ dissociation active center on nanoparticles. The average

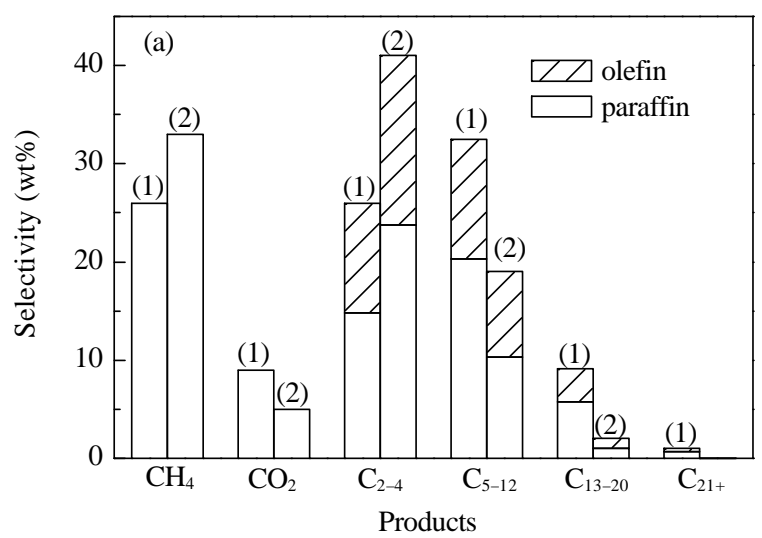

Fig. 6. Hydrocarbon selectivities (a) and Anderson-Schulz-Flory distribution (b) of products for Co-LiBEt ${ }_{3} \mathrm{H}$ (1) and Co- $\mathrm{NaBH}_{4}(2) \mathrm{Catalysts}_{\text {. }}$

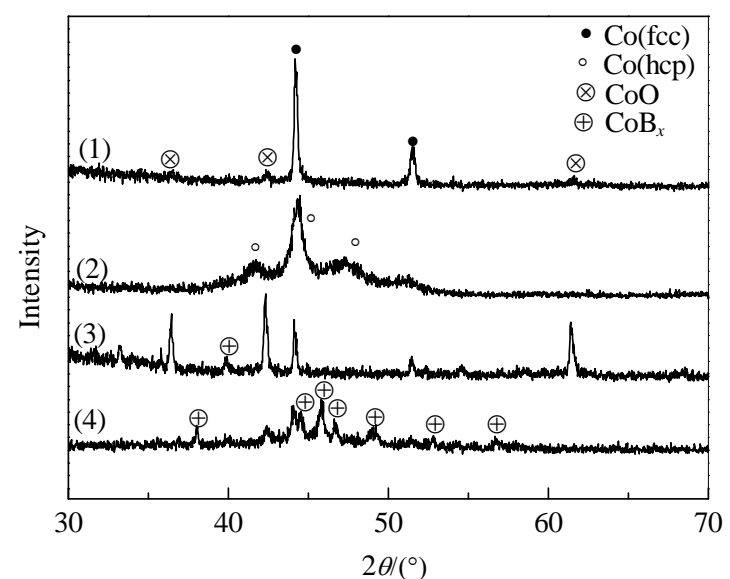

Fig. 7. XRD patterns of $\mathrm{Co}-\mathrm{LiBEt}_{3} \mathrm{H}(1,2)$ and $\mathrm{Co}^{-} \mathrm{NaBH}_{4}(3,4)$ catalysts: before $(2,4)$ and after $(1,3)$ reaction.

size of Co-LiBEt $3 \mathrm{H}$ nanoparticles is $5.9 \mathrm{~nm}$, which is around the optimal particle size. While the average size of $\mathrm{Co}-\mathrm{NaBH}_{4}$ nanoparticles is $3 \mathrm{~nm}$, which is too small to be conducive to synthesis. This is consistent with the results reported by Bezemer et al. [29].

\subsection{Research on B-doping of Co catalysts}

Except the effect of particle size, one of the other reasons for the different reactivity between $\mathrm{Co}-\mathrm{LiBEt}_{3} \mathrm{H}$ and $\mathrm{Co}-\mathrm{NaBH}_{4}$ catalysts is their different structure. Different reduction methods usually determine the composition, structure, and stability of nanoparticles. Many results indicate that B-doping is general in the nanoparticles reduced by $\mathrm{LiBEt}_{3} \mathrm{H}$ and $\mathrm{NaBH}_{4}$, which allows metals to exist in the form of borate and thus affects the reactivity [30]. There are also a lot of research on the effects of B-doping to Co-based catalysts for Fischer-Tropsch synthesis. Li et al. [31] studied the effect of $\mathrm{B}$ on $\mathrm{Co} / \mathrm{TiO}_{2}$ catalyst and found that $\mathrm{B}$ could decrease the reduction degree of Co and excess B could noticeably reduce the activity and selectivity of Fischer-Tropsch synthesis. Figure 7 shows the XRD patterns of fresh and used catalysts. As for fresh $\mathrm{Co}-\mathrm{NaBH}_{4}$, even though the average particle size is only $14 \mathrm{~nm}$, the peak signal of Co(111) or Co(0001) is unobvious, which represents a bad

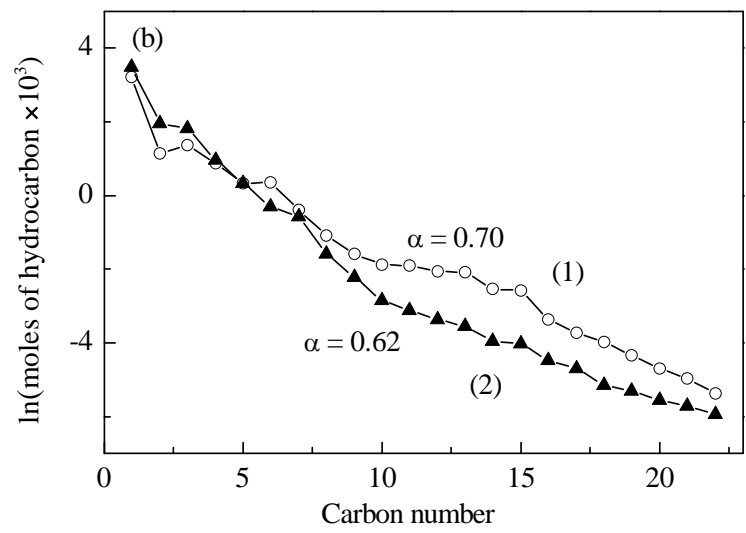


crystalline degree of Co and a major amorphous state of Co, while a strong peak signal of $\mathrm{CoB}_{x}$ indicates that B-Co alloy is the major form of Co. There is no obvious peak signal of used Co- $\mathrm{NaBH}_{4}$ catalyst due to too small particle size. After calcined the catalyst at $400^{\circ} \mathrm{C}$ for $2 \mathrm{~h}$ with $\mathrm{N}_{2}$ purging, many $\mathrm{CoO}$ and a small amount of Co(111) diffraction peak signals can be observed. As for fresh Co-LiBEt ${ }_{3} \mathrm{H}$, the diffraction peak signal of Co(111) are obvious, which accompanied with diffraction peak signal of $\mathrm{Co}(0001)$. However, the signal of $\mathrm{CoB}_{x}$ is covered by those of $\operatorname{Co}(111)$ and $\operatorname{Co}(0001)$, which means that the structure of $\mathrm{CoB}_{x}$ is rare. The peak signal of used Co-LiBEt $3 \mathrm{H}$ catalyst is still in the major of $\mathrm{Co}(111)$ with a little of signal of CoO. These XRD results indicate that the heavy B-doping in $\mathrm{Co}-\mathrm{NaBH}_{4}$ causes a mainly structural presence of B-Co alloy in the catalyst which allows Co to form crystalline phase hardly. In the process of reaction, the reconstruction of $\mathrm{CoB}_{x}$ under effects of water and syngas will form $\mathrm{CoO}$; at the same time, Co is shattered to 3 $\mathrm{nm}$ of ultrafine nanoparticles in the reconstruction due to the presence of metastable amorphous Co.

The low level of $\mathrm{B}$ doping in $\mathrm{Co}-\mathrm{LiBEt}_{3} \mathrm{H}$ allows $\mathrm{B}$ leaving the system as $\mathrm{BEt}_{3}$ form when reduced by $\mathrm{LiBEt}_{3} \mathrm{H}$, which results in better purity and crystalline of Co catalyst. The diffraction peak signal of $\operatorname{Co}(111)$ and $\operatorname{Co}(0001)$ indicates the fcc and hcp structures existing at the same time and fcc Co is the majority. According to the literature, fcc Co is a major form when the particle size is less than $20 \mathrm{~nm}$, which coincides with the observed signal of $\mathrm{Co}(111)$. There is no noticeable signal of $\mathrm{CoB}_{x}$, which indicates effect of B-doping on structure is small. Although the signal of $\mathrm{CoO}$ increases slightly, which means a minor oxidation happened in the process, its signal is still much lower than that of pure Co. These results indicate that when 8.3 $\mathrm{nm}$ of Co reconstructs to the smaller $5.9 \mathrm{~nm}$ of pure Co nanoparticles, the mixed phase of two structures also changed to single fcc Co phase due to the stability of fcc. Co(fcc) also exhibits good catalytic performance for Fischer-Tropsch synthesis.

Table 3 shows the concentration of Co and B of two catalysts before and after the reaction, which is a more direct comparison of contents of $\mathrm{Co}$ and $\mathrm{B}$ in the system. Before the reaction, the concentration of $\mathrm{Co}$ and $\mathrm{B}$ in $\mathrm{Co}^{-\mathrm{NaBH}_{4}}$ is 3.81 and 3.51 $\mu \mathrm{g} / \mathrm{mL}$, respectively, and the atom ratio of Co/B is 0.199 . Much $\mathrm{B}$ exists in the catalyst and dopes into Co to form a lot of $\mathrm{CoB}_{x}$ in an alloy status. Co is difficult to form an order structure under the effect of $B$ that the generation of active site of catalyst is blocked. The atom ratio of Co and B is 0.171 , which is similar to the one before reaction. However, considering the tiny XRD signal of $\mathrm{CoB}_{x}$, the B-Co alloy is tend to be amorphous before reaction. As for the Co- $\mathrm{LiBEt}_{3} \mathrm{H}$, the concentration of Co and $\mathrm{B}$ is 2.28 and $0.206 \mu \mathrm{g} / \mathrm{mL}$, respectively, and the atom ratio of $\mathrm{Co} / \mathrm{B}$

Table 3

ICP data of $\mathrm{Co}-\mathrm{LiBEt}_{3} \mathrm{H}$ and $\mathrm{Co}-\mathrm{NaBH}_{4}$ catalysts.

\begin{tabular}{|c|c|c|c|c|}
\hline Catalyst & Reaction & $\begin{array}{l}\text { Co concentra- } \\
\text { tion }(\mu \mathrm{g} / \mathrm{mL})\end{array}$ & $\begin{array}{c}\text { B concentration } \\
(\mu \mathrm{g} / \mathrm{mL})\end{array}$ & $\begin{array}{c}\mathrm{Co} / \mathrm{B} \\
\text { (atom ratio) }\end{array}$ \\
\hline \multirow[t]{2}{*}{$\mathrm{Co}^{-\mathrm{LiBEt}_{3} \mathrm{H}}$} & before & 2.28 & 0.206 & 2.03 \\
\hline & after & 1.30 & 0.146 & 1.63 \\
\hline \multirow[t]{2}{*}{ Co- $\mathrm{NaBH}_{4}$} & before & 3.81 & 3.51 & 0.199 \\
\hline & after & 3.11 & 3.32 & 0.171 \\
\hline
\end{tabular}

is 2.03. B exists in the catalyst as small portion so the effect of $B$ on Co is small. Although XRD results show that the content of $\mathrm{B}$ is half of $\mathrm{Co}, \mathrm{CoB}_{x}$ alloy is not noticeable, and the system is in major of pure Co. This is the reason why Co- $\mathrm{LiBEt}_{3} \mathrm{H}$ shows high catalytic activity and selectivity for Fischer-Tropsch synthesis. After reaction, the atom ratio of $\mathrm{Co} / \mathrm{B}$ is 1.63 , Co is still in majority, and no significant amount of $\mathrm{CoB}_{x}$ alloy is generated. ICP results also indicate that although Co nanoparticles reconstruct their structure and reduce their particle size during the Fischer-Tropsch synthesis, the content ratio of $\mathrm{Co} / \mathrm{B}$ has no obvious change and $\mathrm{B}$ will not be removed from catalyst by reconstruction, which indicates the necessity to decrease the introduction of $\mathrm{B}$ at the preparation step.

\subsection{FTIR research on reconstruction of catalysts}

The characterization of particle size and catalytic activity of catalysts indicate that a reconstruction of Co nanoparticles happened in the reactions; the examination of XRD and ICP show a certain level of B-doping in Co nanoparticles. Conditions of reconstruction, whether $B$ induces reconstruction and how reconstructions affect Fischer-Tropsch synthesis are to be studied. Therefore, we used $\mathrm{CO}$ as probe molecule and in-situ FTIR to study the reconstruction of $\mathrm{Co}-\mathrm{LiBEt}_{3} \mathrm{H}$ and $\mathrm{Co}-\mathrm{NaBH}_{4}$ in reactions.

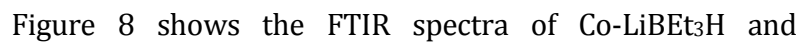
Co-NaBH4. Comparing Fig. 8(a) and (b), under the condition (1), a weak bridge-like adsorption signal at $1849 \mathrm{~cm}^{-1}$ appears for

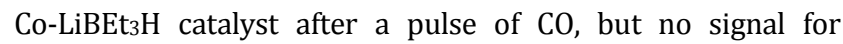
$\mathrm{Co}_{-} \mathrm{NaBH}_{4}$ catalyst. This suggests that $\mathrm{Co}-\mathrm{LiBEt}_{3} \mathrm{H}$ has a faster response and easier chemisorption to $\mathrm{CO}$. Under the condition (2), there are end-like and bridge-like signals at 1976 and 1860 $\mathrm{cm}^{-1}$, respectively, for Co-LiBEt $3 \mathrm{H}$ catalyst. There are similar signals at 1970 and $1840 \mathrm{~cm}^{-1}$ for $\mathrm{Co}-\mathrm{NaBH}_{4}$, which shows a red shift comparing to the former. Tan et al. [33] reported that excessive B-doping would cause a red shift for IR signal. At the same time, the $\mathrm{C}-\mathrm{O}$ bond is weakened and the adsorption of $\mathrm{CO}$ at the surface of metals is strong enough to inhibit subsequent reactions.

Under the conditions of (3), (4), and (5), as for Co- $\mathrm{LiBEt}_{3} \mathrm{H}$ catalyst, the end-like and bridge-like IR adsorptions blue shift to 1985 and $1865 \mathrm{~cm}^{-1}$ when the system reaches reaction temperature. After $1 \mathrm{~h}$ of reaction, the adsorptions further blue shift to 2009 and $1902 \mathrm{~cm}^{-1}$ and then remain stable in subsequent reactions. These blue shifts should result from the decrease of particle size rather than the decrease of B in catalyst, which is due to the fact that the ratio of Co/B doesn't change before and after reactions so that $\mathrm{B}$ cannot be removed out

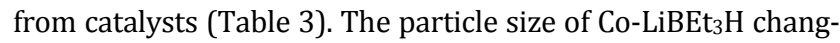
es from 8.3 to $5.9 \mathrm{~nm}$ in the reaction because $B$ takes part in the reconstruction of catalysts, which also changes the electronic properties of metals because of the changes of Co-B structure [33] so that the interaction of metals to $\mathrm{C}-\mathrm{O}$ bond is changed. That is the reason why the changes of particle size can be monitored by FTIR. Reconstruction leads to the blue shift of IR absorption, which weakens the adsorption of metals to $\mathrm{CO}$ so that CO can remove from systems more easily. Actually, under the 

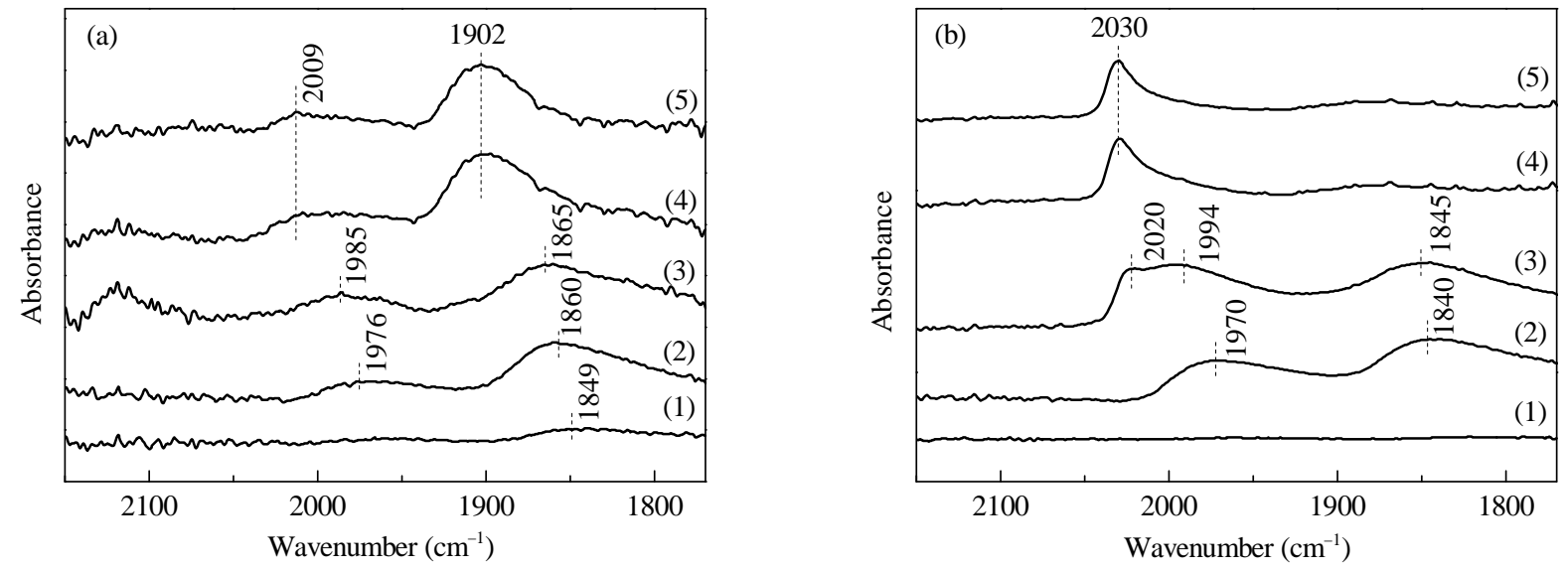

Fig. 8. In-situ FTIR spectra using $\mathrm{CO}$ as probe. (a) $\mathrm{Co}_{-} \mathrm{LiBEt}_{3} \mathrm{H}$; (b) Co- $\mathrm{NaBH}_{4}$. (1) At room temperature, $\mathrm{CO}$ pulse testing under $\mathrm{H}_{2}$ atmosphere; (2) At room temperature, the testing after refilling $3 \mathrm{MPa}$ syngas and mixing for $1 \mathrm{~h}$; (3) At $150^{\circ} \mathrm{C}$, the testing under the condition of $3 \mathrm{MPa}$ of syngas; (4) The testing after $1 \mathrm{~h}$ of reaction; (5) The testing after $2 \mathrm{~h}$ of reaction.

condition (2), the difference of absorption peaks for $\mathrm{Co}_{-} \mathrm{LiBEt}_{3} \mathrm{H}$ and $\mathrm{Co}-\mathrm{NaBH}_{4}$ may result from the difference of initial particle sizes.

As for $\mathrm{Co}-\mathrm{NaBH}_{4}$ catalyst, the linear-like and bridge-like IR absorptions blue shift to 1994 and $1845 \mathrm{~cm}^{-1}$ with weaker strength when the system reaches reaction temperature. At the same time, a new absorption at $2020 \mathrm{~cm}^{-1}$ can be observed, which may represent a reconstructed nanoparticle with very small particle size. After $1 \mathrm{~h}$ reaction, the absorptions at 1994 and $1845 \mathrm{~cm}^{-1}$ disappear, and a new absorption at $2030 \mathrm{~cm}^{-1}$ is observed, which remains stable after $2 \mathrm{~h}$. These observations indicate a process that larger $14 \mathrm{~nm}$ particles are gradually consumed and small $3.1 \mathrm{~nm}$ particles are generated under the reaction conditions. The small particles have no bride-like adsorption, which is an important indicator of activity of the Fischer-Tropsch synthesis [34], so the catalytic activity of 3.1 $\mathrm{nm}$ Co nanoparticles is very low. The activity decreases after reconstructed to small particles. Actually, in the real reactions, an obvious pressure decrease is observed at the first several hours, and reaction rate decreases significantly at late stage of reaction. The case of no activity in recycling reaction also demonstrates that catalysts deactivate quickly.

The FTIR results show that $\mathrm{Co}-\mathrm{LiBEt}_{3} \mathrm{H}$ gradually finishes its reconstruction in $1 \mathrm{~h}$ and the reconstruction leads to the decrease of adsorption of $\mathrm{CO}$ by metals and easily removing of $\mathrm{CO}$ from surface, which are benefit to reactions. The reconstruction of $\mathrm{Co}-\mathrm{NaBH}_{4}$ generates small $3.1 \mathrm{~nm}$ of nanoparticles, which are hard to form a bridge-like adsorption and thus not conducive to Fischer-Tropsch synthesis. Because B induces the reconstructions of both catalysts, the electronic effect is significant enough to red shift the IR adsorptions to be observed conveniently.

\section{Conclusions}

We employed Co nanoparticles reduced by LiBEt $3 \mathrm{H}$ to catalyze aqueous-phase Fischer-Tropsch synthesis, which showed high catalytic activity and recycling ability at low temperature $\left(150^{\circ} \mathrm{C}\right)$. Co nanoparticles reduced by other methods were also evaluated but exhibited poor performance. By comparing the distribution of particle size of $\mathrm{Co}_{-}-\mathrm{LiBEt}_{3} \mathrm{H}$ and $\mathrm{Co}-\mathrm{NaBH}_{4}$ catalysts before and after reaction, catalyst reconstruction occurs during the reaction catalyzed by these two catalysts. Analyzing the composition of nanoparticles and characterizing the structure showed that a certain amount of B-doping in both catalysts happened in the reaction and B-doping in Co- $\mathrm{LiBEt}_{3} \mathrm{H}$ is much less than the other catalyst. In-situ FTIR results showed that a significant reconstruction happened in the reaction and thus caused noticeable adsorption shifts because of the introduction of $B$, which explained the variation of particle size.

\section{References}

[1] Fischer F, Tropsch H. Brennst Chem, 1923, 4: 276

[2] Fischer F, Tropsch H. Brennst Chem, 1926, 7: 97

[3] Huber G W, Iborra S, Corma A. Chem Rev, 2006, 106: 40442

[4] Wang Y, Kang J C, Zhang Q H. Petrochem Technol (王野, 康金灿, 张庆红. 石油化工), 2009, 38: 1255

[5] Vannice M A. J Catal, 1975, 37: 449

[6] Ding M Y, Yang Y, Xiang H W, Li Y W. Chin J Catal (定明月, 杨勇, 相宏伟, 李永旺. 催化学报), 2010, 31: 1145

[7] Xu L Y, Cai G Y, Wang Q X, Chen G Q. J. Fuel Chem Technol (徐龙伢, 蔡光宇，王清遐，陈国权. 燃料化学学报), 1992, 20: 252

[8] Khodakov A Y, Chu W, Fongarland P. Chem Rev, 2007, 107: 1692

[9] Sun Y H, Chen J G, Wang J G, Jia L T, Hou B, Li D B, Zhang J. Chin J Catal (孙予罕, 陈建刚, 王俊刚, 贾丽涛, 侯博, 李德宝, 张娟. 催 化学报), 2010, 31: 919

[10] Shi L H, Chen J G, Fang K G, Sun Y H. Fuel, 2008, 87: 521

[11] Khodakov A Y, Lynch J, Bazin D, Rebours B, Zanier N, Moisson B, Chaumette P. J Catal, 1997, 168: 16

[12] Schanke D, Vada S, Blekkan E A, Hilmen A M, Hoff A, Holmen A.J Catal, 1995, 156: 85

[13] Guczi L, Bazin D, Kovacs I, Borko L, Schay Z, Lynch J, Parent P, Lafon C, Stefler G, Koppány Z, Sajo I. Top Catal, 2002, 20: 129

[14] Bao J, He J J, Zhang Y, Yoneyama Y, Tsubaki N. Angew Chem Int Ed, 2008, 47: 353

[15] Kou Y. Chin J Catal (寇元. 催化学报), 2008, 29: 817

[16] Xiao C X, Cai Z P, Wang T, Kou Y, Yan N. Angew Chem Int Ed, 2008, 47: 746 


\section{Graphical Abstract}

Chin. J. Catal., 2013, 34: 1914-1925 doi: 10.1016/S1872-2067(12)60674-3

\section{Aqueous-phase Fischer-Tropsch synthesis catalyzed by cobalt nanoparticles}

Hang Wang, Yuan Kou*

Peking University
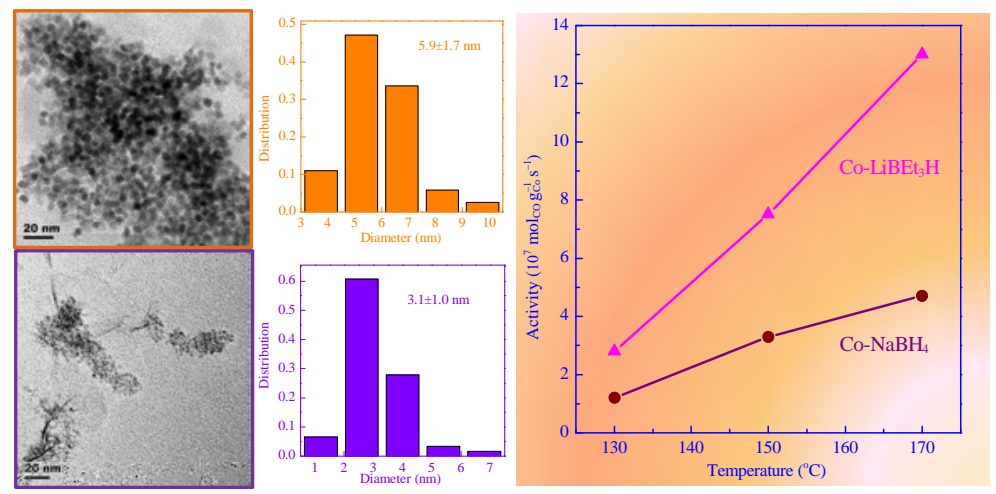

Cobalt nanoparticles prepared by LiBEt ${ }_{3} \mathrm{H}$ reduction undergo a reconstruction process at $150{ }^{\circ} \mathrm{C}$ and $3 \mathrm{MPa}$ syngas $\left(\mathrm{CO}: \mathrm{H}_{2}=1: 2\right)$ and give an activity of $7.4 \times 10^{-7}$ molco $_{\mathrm{gCo}^{-1}} \mathrm{~s}^{-1}$ with $40 \% \mathrm{C}_{5+}$ products, which is the best result in cobalt-catalyzed aqueous-phase Fischer-Tropsch synthesis.

[17] Liu L T, Sun G, Wang C, Yang J H, Xiao C X, Wang H, Ma D, Kou Y. Catal Today, 2012, 183: 136

[18] Quek X Y, Guan Y J, van Santen R A, Hensen E J M. ChemCatChem, 2011, 3: 1735

[19] Wang C, Zhao H B, Wang H, Liu L T, Xiao C X, Ma D. Catal Today, 2012, 183: 143

[20] Fan X B, Tao Z Y, Xiao C X, Liu F, Kou Y. Green Chem, 2010, 12: 795

[21] Cheng X F, Wu B S, Yang Y, Xiang H W, Li Y W. J Mol Catal A, 2010, 329: 103

[22] Silva D O, Scholten J D, Gelesky M A, Teixeira S R, Dos Santos A C B, Souza-Aguiar E F, Dupont J. ChemSusChem, 2008, 1: 291

[23] Yan N, Zhang J G, Tong Y Y, Yao S Y, Xiao C X, Li Z C, Kou Y. Chem Commun, 2009: 4423

[24] Guo Z, Henry L L, Podlaha E J. ECS Trans, 2007, 3: 337

[25] Stevenson J P, Rutnakornpituk M, Vadala M, Esker A R, Charles S
W, Wells S, Dailey J P, Riffle J S.J Magn Magn Mater, 2001, 225: 47

[26] Joseyphus R J, Matsumoto T, Takahashi H, Kodama D, Tohji K, Jeyadevan B. J Solid State Chem, 2007, 180: 3008

[27] Puntes V F, Krishnan K M, Alivisatos A P. Science, 2001, 291: 2115

[28] Bechara R, Balloy D, Vanhove D. Appl Catal A, 2001, 207: 343

[29] Bezemer G L, Bitter J H, Kuipers H P C E, Oosterbeek H, Holewijn J E, Xu X, Kapteijn F, Van Dillen A J, De Jong K P. J Am Chem Soc, 2006, 128: 3956

[30] Cai Z P, Wang H, Xiao C X, Zhong M Q, Ma D, Kou Y. J Mol Catal A, 2010, 330: 94

[31] Li J L, Coville N J. Appl Catal A, 1999, 181: 201

[32] Kitakami O, Sato H, Shimada Y, Sato F, Tanaka M. Phys Rev B, 1997, 56: 13849

[33] Tan K F, Chang J, Borgna A, Saeys M. J Catal, 2011, 280: 50

[34] Song D C, Li J L, Cai Q.J Phys Chem C, 2007, 111: 18970

\section{钴纳米粒子催化水相费托合成 \\ 王 航, 寇 ${ }^{*}$ \\ 北京大学化学与分子工程学院, 北京 100871}

摘要: 水相费托合成可以在远低于传统温度下实现, 其低温高效的特点使其具有重要的应用潜力. 本文制备了水相稳定且可循 环利用的 Co纳米粒子并应用于水相费托反应, $150{ }^{\circ} \mathrm{C}$ 下活性为 $7.4 \times 10^{-7} \mathrm{~mol}_{\mathrm{CO}} \mathrm{g}_{\mathrm{Co}}{ }^{-1} \mathrm{~s}^{-1}, \mathrm{C}_{5}$ 选择性接近 $40 \%$, 是目前纯钴水相费托 合成的最好结果, 而其它方法合成的催化剂在 $150^{\circ} \mathrm{C}$ 时活性低下. 对催化剂进行了粒径、结构、成分测定和原位红外光谱检测, 研 究了催化剂在反应中的重构过程和B掺杂效应.

关键词: 水相费托合成; 钴纳米粒子; 硼掺杂; 原位红外光谱

收稿日期: 2013-01-21. 接受日期: 2013-08-02. 出版日期: 2013-10-20.

*通讯联系人. 电话: (010)62757792; 传真: (010)62751708; 电子信箱: yuankou@pku.edu.cn

基金来源：国家重点基础研究发展计划(973计划, 2013CB933100, 2013CB834603).

本文的英文电子版由Elsevier出版社在ScienceDirect上出版(http://www.sciencedirect.com/science/journal/18722067). 


\section{1. 前言}

费托合成, 即 CO在临氢条件下生成碳氢化合物的 反应, 在合成气的间接液化过程中扮演着重要的角色, 可以将煤、天然气、生物质等能源转化为有价值的化学 品及燃料 ${ }^{[1-5]}$. 在过去的 80 年里, 人们系统研究了担载及 非担载的金属催化剂, 发现铁、钴、钉等过渡金属具有 较好的费托合成活性 ${ }^{[6-10]}$. 钴基催化剂因其具有好的稳 定性、高的重质烃类选择性及相对低的价格成为费托反 应的较好选择 ${ }^{[8-10]}$, 不但有许多工业化的实例, 也有许多 实验室层面上的研究, 诸如催化剂、载体、反应条件等 多种变量 ${ }^{[10-12]} ; \mathrm{Pt}, \mathrm{Ru}$ 和 $\mathrm{Pd}$ 等贵金属助剂也是人们研究 钴系费托合成的热点 ${ }^{[13]}$; 此外, 人们还通过优化反应器 以及多步反应偶合来实现选择性的调控 ${ }^{[14]}$ 等.

考虑到费托合成本身是强放热过程, 将反应在相对 较低的温度下进行热力学上更有利而且更加洁净、绿 色 ${ }^{[15]}$. 在之前的工作中, 本课题组实现了低温高效的水 相费托合成: 用 $2.0 \mathrm{~nm}$ 的 Ru纳米粒子作为催化剂均匀分 散在水中, 可以在低于传统费托合成温度 $50{ }^{\circ} \mathrm{C}$ 的条件下 实现高效转化 ${ }^{[16]}$, 而且催化剂在流动体系中运行 $240 \mathrm{~h}$, 其活性得到良好地保持 ${ }^{[17]}$. 随后, Quek等 ${ }^{[18]}$ 发现表面氧 化的Ru纳米粒子上可以得到 $70 \%$ 以上的含氧产物, 我们 的研究也发现水相费托可以提供研究阴离子助剂的平 台 ${ }^{[19]}$, 这都说明了水相费托的巨大优势. 由于 Ru的价格 过于昂贵而且是全球稀缺资源, Fe 和Co 系催化剂的水相 费托合成往往更具有实际意义, 也更值得我们研究. 不 过, $\mathrm{Fe}$ 的活性物种 $\mathrm{FeC}_{x}$ 难以在水中稳定存在, 使整个过 程较难实现; 退而求其次, 我们与李永旺课题组分别实 现了聚乙二醇相的铁纳米粒子液相费托 ${ }^{[20-21]}$. 而相比于 $\mathrm{Fe}$ 催化剂, Co 可以在水中稳定存在, 这使得钴基水相费 托成为可能. 目前已有一些钴基液相费托的报导, 如 Silva等 ${ }^{[22]}$ 将催化剂置于离子液体 $[\mathrm{Bmim}]\left[\mathrm{NTf}_{2}\right]$ 中在 210 ${ }^{\circ} \mathrm{C} 反$ 应, 活性为 $1.9 \times 10^{-7} \mathrm{~mol}_{\mathrm{CO}} \mathrm{g}_{\mathrm{Co}}{ }^{-1} \mathrm{~s}^{-1}$; 我们实验室将 $\mathrm{Co}$ 纳米粒子均匀分散在角鲨烷中, $200{ }^{\circ} \mathrm{C}$ 得到 $6.1 \times 10^{-6}$ $\mathrm{mol}_{\mathrm{CO}} \mathrm{g}_{\mathrm{Co}}{ }^{-1} \mathrm{~s}^{-1}$ 的活性 ${ }^{[23]}$. 但到目前为止, 仍然鲜有纯Co 纳米粒子催化水相费托合成具有良好反应性能的报道

本文采用 $\mathrm{LiBEt}_{3} \mathrm{H}$ 作为还原剂制备了水相稳定的 Co 纳米粒子并用于水相费托合成，在 $150{ }^{\circ} \mathrm{C}$ 下活性为 $7.4 \times 10^{-7} \mathrm{~mol}_{\mathrm{CO}} \mathrm{g}_{\mathrm{Co}}^{-1} \mathrm{~s}^{-1}$. 而其他方法还原的Co纳米粒子 的费托合成的活性则处于很低水平或无法观测. 随后以 $\mathrm{NaBH}_{4}$ 还原的Co纳米粒子为比较, 研究了两种催化剂的 不同性质。

\section{2. 实验部分}

\section{1. 催化剂的制备}

$\mathrm{LiBEt}_{3} \mathrm{H}$ 还原的Co纳米粒子: 将 $0.26 \mathrm{~g}$ 无水 $\mathrm{CoCl}_{2}$ 与 0.50 g SB3-12 (3-磺丙基十二烷基二甲基甜菜碱内盐, 作 为保护剂)混合溶解于 $30 \mathrm{~mL}$ THF中, 用注射器缓慢将5 $\mathrm{mL} 1 \mathrm{~mol} / \mathrm{L}$ 的 $\mathrm{LiBEt}_{3} \mathrm{H}$ 的 THF 溶液滴加至溶液中, 并伴随 充分搅拌. 混合溶液迅速从蓝色变黑, 表示Co被还原. 反应进行 $10 \mathrm{~min}$ 后, 用 $10 \mathrm{~mL}$ 乙醇淬灭反应, 随后将纳米 粒子用一块永久磁铁分离, 用乙醇洗两次、再用水洗两 次. 随后, 纳米粒子分散在含有 $2.20 \mathrm{~g} \mathrm{PVP}$ (聚乙烯吡咯 烷酮, 作为水相纳米粒子保护剂)的水中用于反应. 记为 $\mathrm{Co}-\mathrm{LiBEt}_{3} \mathrm{H}$.

$\mathrm{NaBH}_{4}$ 还原的 $\mathrm{Co}$ 纳米粒子: 将 $0.50 \mathrm{~g} \mathrm{Co}(\mathrm{OAc})_{2}$. $4 \mathrm{H}_{2} \mathrm{O}$ 与 $2.20 \mathrm{~g}$ PVP混合溶解于 $30 \mathrm{~mL}$ 水中, 加入 $0.40 \mathrm{~g}$ $\mathrm{NaBH}_{4}$ 固体, 并伴随充分搅拌. 混合溶液迅速从红色变 黑, 表示Co以纳米粒子的形式被还原出来. 合成的纳米 粒子被一块永久磁铁分离、水洗两次. 随后, 纳米粒子分 散到含有 $2.20 \mathrm{~g} \mathrm{PVP}$ 的水中用于反应. 记为Co- $\mathrm{NaBH}_{4}$.

其它方法还原的 Co 纳米粒子：对于 $\mathrm{N}_{2} \mathrm{H}_{4}$, $\mathrm{LiAl}(\mathrm{O}-\mathrm{tBu})_{3} \mathrm{H}, \mathrm{KH}$, 乙二醇热还原, $\mathrm{Co}_{2}(\mathrm{CO})_{8}$ 热分解法 制备的Co纳米粒子, 按照文献[24-27]所示方法合成. 但 在油相还原时采用SB3-12作为保护剂, 随后转移到水中 用PVP做保护剂.

以上合成纳米粒子的过程均在 $\mathrm{N}_{2}$ 保护下完成.

\section{2. 催化剂的表征}

纳米粒子的透射电镜(TEM)表征使用Tecnai F-30电 镜, 工作电压为 $300 \mathrm{kV}$. 纳米粒子被去离子水稀释且在 超声下分散 $5 \mathrm{~min}$, 之后滴在附有超薄碳膜的铜网上. 每 个样品的粒子粒径分布统计数量超过 200 个粒子.

样 品 的 $\mathrm{X}$ 射 线 衍 射 (XRD) 测 试 在 Rigaku $\mathrm{D} / \mathrm{MAX}-2400$ 型X射线衍射仪上进行, $\mathrm{Cu} K_{\alpha}$ 辐射源, $\lambda=$ $0.154 \mathrm{~nm}$, 管电压 $30 \mathrm{kV}$, 管电流 $100 \mathrm{~mA}$, 扫描范围 $2 \theta=$ $30^{\circ}-70^{\circ}$, 扫描速度 $2^{\circ} / \mathrm{min}$, 步长 $0.02^{\circ}$. 纳米粒子用磁铁分 离、水洗两次, 之后在真空下干燥, 对粉末进行测定.

样品的 $\mathrm{Co}$ 和B含量测定是利用电感耦合等离子体 发射光谱(ICP, Perkin Elmer Optima 2000 DV), 用硝酸和 盐酸来溶解样品.

催化剂的CO吸附原位红外光谱表征(FTIR)采用自 制的原位红外装置, 工作条件为 $150{ }^{\circ} \mathrm{C}, 3 \mathrm{MPa}$. 采集红 外信息利用Bruker TENSOR 27型红外光谱仪, 分辨率为 $2 \mathrm{~cm}^{-1}$, 采集次数为64次. 


\section{3. 催化剂的评价}

Co纳米粒子的费托合成性能评价在封闭搅拌式反 应釜中进行. 将Co纳米粒子分散在 $40 \mathrm{~mL}$ 水中, 转移到 不锈钢反应釜, 置换 3 次 $\mathrm{N}_{2}$, 之后充入 $3.0 \mathrm{MPa}$ 合成气 $\left(\mathrm{CO}: \mathrm{H}_{2}: \mathrm{Ar}=32: 64: 4\right)$. 反应釜升到指定温度, 充分搅拌 (600 r/min)进行反应; 当压力降到2.0-2.5 MPa时停止反 应并进行检测. 除速率过慢的反应外, 反应时间一般为 24-48 h之间.

反应后恢复常温, 将反应釜连接到气相色谱以分析 气体产物. 随后在反应釜中注入 $20.0 \mathrm{mg}$ 十氢萗作为内 标、 $10 \mathrm{~mL}$ 环己烷作为萃取剂, $150{ }^{\circ} \mathrm{C}$ 加热搅拌 $2 \mathrm{~h}$, 恢复 常温, 分离得到环己烷相, 进行气相色谱分析以确定液 体产物.

对于循环实验, 待反应完成后, 将Co纳米粒子用磁 铁吸下来, 去离子水洗 2 次后加入含有 $2.20 \mathrm{~g} \mathrm{PVP}$ 的水中 分散, 转移到不锈钢反应釜中进行反应. 过程在 $\mathrm{N}_{2}$ 保护 下完成.

\section{3. 结果与讨论}

\subsection{Co 纳米粒子的粒径分布}

利用不同还原方法得到的 $\mathrm{Co}$ 催化剂的电镜结果见 图1-3. 图1为Co- $\mathrm{LiBEt}_{3} \mathrm{H}$ 反应前后的 TEM照片和粒径 分布. 可以看到, 新鲜的 $\mathrm{Co}$ 纳米粒子平均粒径为 $8.3 \mathrm{~nm}$. 进行一次费托合成后, 在产物的包裹下粒子有一定的物 理聚集, 但仍较易区分, 其平均粒径为 $5.9 \mathrm{~nm}$, 这说明在 费托合成的条件下纳米粒子发生了重构, 粒径发生变化. 反应后的纳米粒子在之后的多次反应后粒径基本保持 不变, 如图1(c)所示, 循环一次后平均粒径为 $5.7 \mathrm{~nm}$, 说 明了 $5.9 \mathrm{~nm}$ 的Co纳米粒子在反应中具有较好的稳定性.

对于图2的 Co- $\mathrm{NaBH}_{4}$ 纳米粒子, 其反应前后粒径有 明显的变化: 反应前平均粒径为 $14 \mathrm{~nm}$, 且分布很宽; 而 反应后只有 $3.1 \mathrm{~nm}$. 此外, 该Co纳米粒子在反应后失去 磁性, 无法用磁铁进行分离.

$\mathrm{N}_{2} \mathrm{H}_{4}, \mathrm{LiAl}(\mathrm{O}-\mathrm{t} \mathrm{Bu})_{3} \mathrm{H}$ 和 KH还原的 Co 粒子如图 3 所 示. 由于还原的 $\mathrm{Co}$ 纳米粒子存在明显的聚积, 粘连成较 大的片状结构而无法很好地分散, 呈絮状形式存在, 不 适合用做费托合成的催化剂.

乙二醇热还原、 $\mathrm{Co}_{2}(\mathrm{CO})_{8}$ 热分解制备的 $\mathrm{Co}$ 催化剂如 图4所示. 由于采用与金属相互作用不强的SB3-12保护 剂(相较于油酸保护剂), 而且制备温度较高, 得到的粒径 分别为 340 和 $31 \mathrm{~nm}$, 粒径过大, 同样不适合进行反应.

\section{2. 催化剂的费托合成反应性能}

不同 Co 催化剂的费托合成活性如表 1 所示. $\mathrm{Co}-\mathrm{LiBEt}_{3} \mathrm{H}$ 在 $130{ }^{\circ} \mathrm{C}$ 即表现出了明显的活性, 在 $150{ }^{\circ} \mathrm{C}$ 时为 $7.4 \times 10^{-7} \mathrm{~mol}_{\mathrm{CO}} \mathrm{g}_{\mathrm{Co}}{ }^{-1} \mathrm{~s}^{-1}$, 与 Bechara等 ${ }^{[28]}$ 在 $\mathrm{Co} / \mathrm{Al}_{2} \mathrm{O}_{3}$ 催化剂上 $190{ }^{\circ} \mathrm{C}$ 的数据相当, 而升到 $170{ }^{\circ} \mathrm{C}$ 时活性上升 为 $1.3 \times 10^{-6} \mathrm{~mol}_{\mathrm{CO}} \mathrm{g}_{\mathrm{Co}}{ }^{-1} \mathrm{~s}^{-1}$. 将该催化剂在 $150{ }^{\circ} \mathrm{C}$ 条件下 进行五次循环 (实验4-8), 活性依次为 $6.7 \times 10^{-7}, 5.9 \times 10^{-7}$, $5.4 \times 10^{-7}$ 和 $5.2 \times 10^{-7} \mathrm{~mol}_{\mathrm{CO}} \mathrm{g}_{\mathrm{Co}}{ }^{-1} \mathrm{~s}^{-1}$, 保持相对稳定. 这说 明催化剂在反应后可以较好地循环利用, 也表明在反应 过程中, $8.3 \mathrm{~nm}$ 的Co纳米粒子在重构为 $5.9 \mathrm{~nm}$ 的Co纳米 粒子后可以稳定存在, 进而使得催化活性得到了较好的 保持.

对于 $\mathrm{Co}-\mathrm{NaBH}_{4}$, 在 $130-170{ }^{\circ} \mathrm{C}$ 时的活性都不及 $\mathrm{Co}-\mathrm{LiBEt}_{3} \mathrm{H}$. 图 5 为催化剂活性的对数与 $1 / T$ 的关系图. 可以看出, Co- $\mathrm{LiBEt}_{3} \mathrm{H}$ 均在Co- $\mathrm{NaBH}_{4}$ 上方, 两者活化能 分别为 57 和 $45 \mathrm{~kJ} / \mathrm{mol}$. 此外, $\mathrm{Co}-\mathrm{NaBH}_{4}$ 在 $150{ }^{\circ} \mathrm{C}$ 下进行 一次反应即失去活性, 实验 12 的循环反应活性几乎为 0 , 这说明初始的Co纳米粒子在重构为 $3.1 \mathrm{~nm}$ 之后催化性 能明显下降. 对于 $\mathrm{N}_{2} \mathrm{H}_{4}, \mathrm{LiAl}(\mathrm{O}-\mathrm{tBu})_{3} \mathrm{H}, \mathrm{KH}$ 还原, 乙二 醇热还原及 $\mathrm{Co}_{2}(\mathrm{CO})_{8}$ 热分解得到的催化剂, 在 $150{ }^{\circ} \mathrm{C}$ 下 均未观测到费托合成活性(实验13-17).

Co- $\mathrm{LiBEt}_{3} \mathrm{H}$ 与 $\mathrm{Co}-\mathrm{NaBH}_{4}$ 催化剂的选择性如表 2 和 图6所示. 在 $150{ }^{\circ} \mathrm{C}$ 时, Co- $\mathrm{LiBEt}_{3} \mathrm{H}$ 催化的费托合成产物 中有 $26 \%$ 甲烷, $26 \% \mathrm{C}_{2-4}$ 和近 $40 \%$ 的 $\mathrm{C}_{5+}$ 产物; 升温到 170 ${ }^{\circ} \mathrm{C}$ 时, 甲烷有所升高, $\mathrm{C}_{5+}$ 有所下降. 从图6(a)的产物选择 性图中可看到, $\mathrm{C}_{2+}$ 产物中烯烃占有产物的近一半(烯烃 比例 $\mathrm{C}_{2-4}$ 为 $43 \%, \mathrm{C}_{5-12}$ 为 $37 \%, \mathrm{C}_{13+}$ 为 $37 \%$ ), 这也是低温反 应的特有结果. 对于 $\mathrm{Co}-\mathrm{NaBH}_{4}, 150{ }^{\circ} \mathrm{C}$ 条件的产物中有 $33 \%$ 甲烷, $40 \%$ 以上 $\mathrm{C}_{2-4}, \mathrm{C}_{5+}$ 仅有 $20 \%$, 烯烃分布与 $\mathrm{Co}-\mathrm{LiBEt}_{3} \mathrm{H}$ 相近; 在 $170{ }^{\circ} \mathrm{C}$ 时 $\mathrm{C}_{5+}$ 会进一步减少; 如果采 用 CO: $\mathrm{H}_{2}=1: 10$ 的气体, 在 $150{ }^{\circ} \mathrm{C}$ 条件下甲烷可达 $56 \%$, $\mathrm{C}_{5+}$ 仅有 $6 \%$. 这说明 $\mathrm{Co}-\mathrm{LiBEt}_{3} \mathrm{H}$ 的链增长能力明显优于 $\mathrm{Co}-\mathrm{NaBH}_{4}$. 从图 6(b) 可知, 两种催化剂的产物均符合 Schulz-Flory分布, 前者的链增长因子为 0.70 , 高于后者 的 0.62 .

以上数据表明, $\mathrm{Co}-\mathrm{LiBEt}_{3} \mathrm{H}$ 的费托合成活性、循环 性能以及重质烃类的选择性均优于 $\mathrm{Co}-\mathrm{NaBH}_{4}$ 催化剂, 其原因之一是两种催化剂粒径的差异. Bezemer等 ${ }^{[29]}$ 在 碳纤维上负载了不同粒径的Co催化剂用于费托合成, 发 现Co催化剂的粒径需要在 $6 \mathrm{~nm}$ 左右以达到最佳, 在低于 $6 \mathrm{~nm}$ 时活性会显著下降. 这是因为在Co纳米粒子粒径 较低时, $\mathrm{CO}$ 不易在 $\mathrm{Co}$ 表面上脱附从而导致后续反应难 以进行, 而且纳米粒子上也不容易形成 $\mathrm{B}_{5} \mathrm{CO}$ 解离活性 
中心, 导致活性和选择性降低. 本工作所合成的 $\mathrm{Co}-\mathrm{LiBEt}_{3} \mathrm{H}$ 在反应中重构得到的纳米粒子粒径约为 5.9 $\mathrm{nm}$, 处于最佳粒径附近, 而Co- $\mathrm{NaBH}_{4}$ 重构后为 $3 \mathrm{~nm}$, 粒 径过小因而不利于反应. 这与Bezemer等 ${ }^{[29]}$ 的结果相符.

\subsection{Co催化剂中B掺杂的研究}

除粒径效应之外, Co- $\mathrm{LiBEt}_{3} \mathrm{H}$ 与 $\mathrm{Co}-\mathrm{NaBH}_{4}$ 催化性 能不同的另一个原因是其具有不同的结构. 不同的还原 方法往往决定了纳米粒子的成分、结构和稳定性. 研究 表明, $\mathrm{B}$ 掺杂在 $\mathrm{NaBH}_{4}$ 及 $\mathrm{LiBEt}_{3} \mathrm{H}$ 还原制备的纳米粒子中 普遍存在, 使得金属以硼化物的非 0 价形式存在, 从而影 响催化性能 ${ }^{[30]}$; B掺杂对Co基费托合成的影响也有很多 研究, 李金林等 ${ }^{[31]}$ 研究了 $\mathrm{B}$ 对 $\mathrm{Co} / \mathrm{TiO}_{2}$ 催化剂的影响, 发 现 $\mathrm{B}$ 可以降低Co的还原度, 过量的 $\mathrm{B}$ 可以显著降低费托 合成活性和选择性. 为此, 两种催化剂分别进行了反应 前后的 XRD 实验, 结果如图 7 所示. 对于新鲜的 $\mathrm{Co}-\mathrm{NaBH}_{4}$, 虽然平均粒径有 $14 \mathrm{~nm}$, 但 $\mathrm{Co}(111)$ 或 $\operatorname{Co}(0001)$ 的信号都不明显, Co的晶态程度很差, 多以无 定形存在; 而 $\mathrm{CoB}_{x}$ 的信号较强, 表明 $\mathrm{Co}-\mathrm{NaBH}_{4}$ 的 Co以 $\mathrm{Co}-\mathrm{B}$ 合金为主. 反应后的Co- $\mathrm{NaBH}_{4}$ 由于粒径过小而没 有明显XRD信号, 因此将样品在 $400{ }^{\circ} \mathrm{C} \mathrm{N}_{2}$ 焙烧 $2 \mathrm{~h}$ 后进 行XRD实验, 得到如图7(b)所示的谱图, 出现了明显的 $\mathrm{CoO}$ 衍射峰以及较弱的 $\mathrm{Co}(111)$ 衍射峰. 对于新鲜的 $\mathrm{Co}-\mathrm{LiBEt}_{3} \mathrm{H}$, 其 $\mathrm{Co}(111)$ 衍射峰很明显, 同时伴有 $\mathrm{Co}(0001)$ 的衍射峰, 而 $\mathrm{CoB}_{x}$ 信号淹没在 $\mathrm{Co}(111)$ 与 $\mathrm{Co}(0001)$ 中, 表明 $\mathrm{CoB}_{x}$ 结构并不明显; 反应后的样品出 现少量的 $\mathrm{CoO}$ 衍射峰, 但仍以 $\mathrm{Co}(111)$ 为主. XRD结果表 明, 在Co- $\mathrm{NaBH}_{4}$ 中, $\mathrm{B}$ 的大量掺杂使得 $\mathrm{Co}$ 主要以Co-B合 金结构存在, Co 并不是以 0 价存在于体系中, 而且难以形 成晶相, 几乎看不到 $\operatorname{Co}(111)$ 的衍射峰. 在反应过程中, $\mathrm{CoB}_{x}$ 会在水、合成气的作用下进行重构, $\mathrm{Co}$ 脱离B而形 成了 $\mathrm{CoO}$; 同时因为 $\mathrm{Co}$ 以亚稳定的非晶态存在, 所以重 构为 $3 \mathrm{~nm}$ 的超细Co纳米粒子.

在Co- $\mathrm{LiBEt}_{3} \mathrm{H}$ 中, B 的掺杂程度明显较低, $\mathrm{LiBEt}_{3} \mathrm{H}$ 还原时 $\mathrm{B}$ 多以 $\mathrm{BEt}_{3}$ 的形式离开体系, 所以得到的Co相对 较纯净, 同时晶化程度较好, $\operatorname{Co}(111)$ 和 $\operatorname{Co}(0001)$ 衍射峰 表明 fcc 与 hcp 结构同时存在, 以fcc Co 为主. 研究表 明 ${ }^{[32]}$, Co 在粒径小于 $20 \mathrm{~nm}$ 时主要以fcc结构存在, 这与 本实验中观测到的 $\operatorname{Co}(111)$ 信号吻合. 在反应后, 样品的 $\operatorname{Co}(0001)$ 信号几乎消失, Co以fcc的Co(111)存在. 没有出 现明显的 $\mathrm{CoB}_{x}$ 信号, 表明 $\mathrm{B}$ 掺杂对其结构影响很小; $\mathrm{CoO}$ 的衍射峰强度略有上升, 表明在反应过程中可能存 在少量的氧化, 但这种氧化不占主导地位, $\mathrm{CoO}$ 衍射峰
强度比纯Co要低很多. 这说明在反应过程中, $8.3 \mathrm{~nm}$ 的 Co 会重构为 $5.9 \mathrm{~nm}$, 粒径变小, fcc结构更加稳定, 从而由 两种结构的混相转变为单一的fcc Co结构, 后者也具有 良好的费托合成性能.

表3给出了两种催化剂在反应前后 Co 和B的浓度. 在反应前, $\mathrm{Co}-\mathrm{NaBH}_{4}$ 中的Co浓度为 $3.81 \mu \mathrm{g} / \mathrm{mL}, \mathrm{B}$ 浓度 为 $3.51 \mu \mathrm{g} / \mathrm{mL}, \mathrm{Co}$ 与 $\mathrm{B}$ 的原子比为 0.199 , B在催化剂中大 量存在, 而且会与 $\mathrm{Co}$ 掺杂形成大量的 $\mathrm{CoB}_{x}$, 使得倾向于 无序的 $\mathrm{CoB}_{x}$ 以合金形式存在; 同时在 $\mathrm{B}$ 的影响下Co难以 很好地形成有序结构, 因而抑制了催化剂活性位的形成. 反应后的 $\mathrm{Co} / \mathrm{B}$ 原子比为 0.171 , 与反应前差别不大, 但结 合 XRD谱图上仅有的很小 $\mathrm{CoB}_{x}$ 衍射峰, 说明反应前 $\mathrm{Co}-\mathrm{NaBH}_{4}$ 的Co-B合金趋于无定形化. 对于Co- $\mathrm{LiBEt}_{3} \mathrm{H}$, 其反应前 $\mathrm{Co}$ 浓度为 $2.28 \mu \mathrm{g} / \mathrm{mL}$, 而 B 浓度仅有 0.206 $\mu \mathrm{g} / \mathrm{mL}, \mathrm{Co}$ 与 B 的原子比为 2.03 , B 在样品中并非大量存 在, 对Co的影响很小; XRD也表明体系中的Co物种以纯 Co为主, 因而表现出较好的活性和选择性. 反应后, $\mathrm{Co} / \mathrm{B}$ 原子比为 $1.63, \mathrm{Co}$ 仍占多数, 且样品中未形成可观 的 $\mathrm{CoB}_{x}$ 合金. ICP结果同时表明在费托合成前后, 虽然 $\mathrm{Co}$ 纳米粒子进行重构、粒径变小, 但 $\mathrm{Co}$ 与 $\mathrm{B}$ 的含量比例 没有太大的变化, B并不会因为重构而脱离催化剂, 所以 必须在制备时降低B的引入.

\subsection{FTIR结果}

综上, Co 纳米粒子在反应中存在重构现象和不同程 度的B掺杂. 重构发生条件、B是否会诱导重构、重构如 何影响费托合成反应等有待研究. 为此, 我们以CO为探 针分子利用原位FTIR来检测在实际反应中Co- $\mathrm{LiBEt}_{3} \mathrm{H}$ 与 $\mathrm{Co}-\mathrm{NaBH}_{4}$ 两种催化剂在反应中的重构行为. 图8所示 为 $\mathrm{Co}-\mathrm{LiBEt}_{3} \mathrm{H}$ 和 Co- $\mathrm{NaBH}_{4}$ 的原位红外光谱. 可以看出, 在(1)条件下, 体系中打入CO脉冲后, $\mathrm{Co}-\mathrm{LiBEt}_{3} \mathrm{H}$ 在1849 $\mathrm{cm}^{-1}$ 处出现了一个较弱的桥式吸附信号, 而Co- $\mathrm{NaBH}_{4}$ 没 有出现任何信号. 这说明前者对CO响应更快, 更容易进 行CO的化学吸附. 在(2)条件下, Co- $\mathrm{LiBEt}_{3} \mathrm{H}$ 分别在1976 和 $1860 \mathrm{~cm}^{-1}$ 处出现了端式和桥式吸附, $\mathrm{Co}-\mathrm{NaBH}_{4}$ 则分 别位于 1970 和 $1840 \mathrm{~cm}^{-1}$ 处, 比前者有较明显的红移. 从 Tan等 ${ }^{[33]}$ 的工作得知, 过多的B掺杂会导致红外信号红 移, 同时 $\mathrm{C}-\mathrm{O}$ 键被削弱、 $\mathrm{CO}$ 在金属表面吸附过强因而会 抑制后续反应.

在(3), (4)和(5)条件下, 对于 Co- $\mathrm{LiBEt}_{3} \mathrm{H}$, 当体系达 到反应温度后, 端式与桥式 $\mathrm{CO}$ 的红外吸收峰蓝移至 1985 和 $1865 \mathrm{~cm}^{-1}$ 处; 反应约 $1 \mathrm{~h}$ 后进一步蓝移到 2009 和 $1902 \mathrm{~cm}^{-1}$ 处, 随后基本没有太大的变化. 从表 3 得知, 反 
应后 $\mathrm{Co} / \mathrm{B}$ 原子比不会上升, B并不会从催化剂中脱离, 所 以蓝移应该归于粒径的降低. Co- $\mathrm{LiBEt}_{3} \mathrm{H}$ 的粒径从反应 前的 $8.3 \mathrm{~nm}$ 到反应后的 $5.9 \mathrm{~nm}$, 因为两种催化剂的重构 都存在 $\mathrm{B}$ 的参与, 不仅会导致粒径的变化, 也会因Co-B 结构改变使得金属的电子性质发生变化 ${ }^{[33]}$, 从而使得金 属对 $\mathrm{C}-\mathrm{O}$ 键的作用发生变化, 所以粒径变化可以通过红 外吸收峰的位移来观测到. 重构使得吸收峰蓝移, 金属 对CO的吸附减弱, CO更加容易脱离体系, 从而使后续反 应容易发生. 实际上, 对于 (2)条件, 红外吸收峰位置的 不同也有可能是 $\mathrm{Co}-\mathrm{LiBEt}_{3} \mathrm{H}$ 与 $\mathrm{Co}-\mathrm{NaBH}_{4}$ 的初始粒径不 同所致.

而对于 $\mathrm{Co}-\mathrm{NaBH}_{4}$, 当体系达到反应温度后, 端式与 桥式CO吸收峰蓝移至1994和 $1845 \mathrm{~cm}^{-1}$ 处, 其强度有所 减弱, 同时在 $2020 \mathrm{~cm}^{-1}$ 处出现一新的吸收峰. 该吸收峰 应对应于经重构后粒径很小的纳米粒子, 其费托合成活 性较低; 在反应约 $1 \mathrm{~h}$ 后, 1994 和 $1845 \mathrm{~cm}^{-1}$ 处的峰消失, 在 $2030 \mathrm{~cm}^{-1}$ 处出现了一个新的吸收峰, 且反应 $2 \mathrm{~h}$ 后基 本没有变化. 这说明在反应条件下, 较大的 $14 \mathrm{~nm}$ 粒子逐 渐被消耗、形成粒径较小的 $3.1 \mathrm{~nm}$ 粒子的过程. 较小的 粒子上没有桥式吸附CO信号, 而桥式吸附是费托活性
的重要指标 ${ }^{[34]}$, 因而费托活性很低, 以致很快失活.

原位FTIR结果表明, $\mathrm{Co}-\mathrm{LiBEt}_{3} \mathrm{H}$ 在反应条件下会逐 渐重构, 反应 $1 \mathrm{~h}$ 后基本完成. 重构使得金属吸附CO的 能力下降、导致CO更容易从表面脱除从而利于反应. 而 $\mathrm{Co}-\mathrm{NaBH}_{4}$ 在反应过程中也存在重构, Co粒子重构成3.1 $\mathrm{nm}$ 的较小粒子, 难以形成桥式吸附因而不利于费托合 成. 由于两种催化剂都存在B掺杂, 重构在B诱导下进 行, 电子效应比较明显, 红外吸收峰的位置有明显移动 因而易于红外观测.

\section{4. 结论}

$\mathrm{LiBEt}_{3} \mathrm{H}$ 还原的Co纳米粒子催化剂催化水相费托合 成, 在低温 $\left(150^{\circ} \mathrm{C}\right)$ 下具有良好的催化性能和循环能力. 其它方法还原的Co纳米粒子同样被用做水相费托的评 价, 但效果均不佳. $\mathrm{LiBEt}_{3} \mathrm{H}$ 和 $\mathrm{NaBH}_{4}$ 还原得到的两种催 化剂在反应过程中都存在重构行为及不同程度的 $\mathrm{B}$ 掺 杂, 其中 $\mathrm{LiBEt}_{3} \mathrm{H}$ 作为还原剂时 $\mathrm{B}$ 掺杂明显较少. 原位 FTIR结果表明, Co纳米粒子在反应过程中重构现象明 显, 这种重构因由 $\mathrm{B}$ 的引入而使得吸收峰位移明显, 从而 很好地解释了粒径的变化规律. 